\title{
Why is it Difficult to Talk About the (Coherent) Post-Communist Welfare State Model? Comparative Analysis of the Czech Republic, Lithuania and Romania
}

\author{
GIEDRÉ SVIRBUTAITE்-KRUTKIENE், ARVYDAS GUOGIS \\ Institute of Public Administration, Faculty of Public Governance and Business, Mykolas Romeris University, 20 Ateities Street, 08303 \\ Vilnius, Lithuania \\ Email: giedre.svirbutaite@gmail.com; arvydasg@mruni.eu
}

\begin{abstract}
The study of welfare states, after the substantiation of the classical typologies of R. Titmuss and G. Esping-Andersen at the end of the last century, is being developed by other authors, one of the original works of which is the modelling of post-communist Central and Eastern European (CEE) states. Despite some similarities in the CEE countries, they also show significant differences in welfare provision, as confirmed by statistical and comparative analysis of the Czech Republic, Lithuania and Romania. The authors of the article argue that it is scientifically difficult to speak of a coherent post-communist welfare state model. Instead, several models of welfare states should be defined in CEE.
\end{abstract}

Keywords: welfare state model, social model, post-communist countries

\section{INTRODUCTION}

The global COVID-19 crisis in 2020 has revealed that the most important structural and functional element of the world order remains the state, which methodologically contradicts the neoliberal approach that has dominated for several decades. The post-communist countries of Central and Eastern Europe were no exception in this sense: they no longer shaped their policies in a 'golden' but a 'silver' or even 'bronze' period of welfare state-building (Moreno 2016), which was not more favourable to egalitarianism or ideas and practices that tend to be more socially just. However, the COVID-19 crisis has highlighted the need to build an effective state or to maintain it in a good shape as nation states grow in importance in the world and the role of globalization diminishes.

The Danish political scientist and sociologist G. Esping-Andersen, based on the typology of welfare of the English sociologist R. Titmuss (Titmuss 1974), applied and substantiated the most common classification of welfare state regimes (models) in political science - based 
on the correlation of the state, market and family three models of the welfare state were distinguished - liberal, conservative-corporate, and social-democratic (redistributive) (Esping-Andersen 1990). Esping-Andersen analysed welfare state models from a socio-economic perspective, also taking into account state policies and the role of the state in social security and chose developed world countries as examples of welfare models.

Despite the widespread prevalence and recognition of this classification in the scientific community, Esping-Andersen's classification of welfare regimes has received considerable criticism, largely for its rigor, as not all states can be assigned to any of these three models. Some countries undoubtedly reflect the Esping-Andersen typology, for example, Sweden is most reminiscent of the social democratic model, Germany is more conservative-corporate, and so on. However, there are a number of states that have certain features that are common to several welfare state models, or in other words, do not have a 'pure' form of a particular model. This only shows that it is impossible to fit all the different cases of the world into just three models. Therefore, there are many attempts in the scientific community to adjust the Esping-Andersen typology, usually extending and adding it with one or more models (for example, the Southern European model, the European Union model, the Soviet model, etc.). Based on the typology of models, an attempt is made to define the newly formed types (models) of social welfare in Central and Eastern European countries.

Some authors unite all post-communist states into one (coherent) social (welfare) model and seek to expand Esping-Andersen's typology of three models, which has become traditional. Although each post-communist state has the characteristics of the Esping-Andersen typology, the existence of post-communist model is often argued based on countries common past (the influence of the communist regime), the influence of European Union membership and similar political, economic and social reforms to create welfare systems and ensure access to social security and social services for its citizens. Nevertheless, there are fundamental differences between post-communist states, leading to hesitation in the idea of a single (coherent) post-communist welfare state model. With this in mind, the aim of the article is to identify and analyse the internal (inter-state) differences of the post-communist welfare state model. To achieve this goal, the following tasks are set:

1. To examine the post-communist model of the welfare state and its characteristic features;

2. To conduct a comparative analysis of the selected countries - the Czech Republic, Lithuania and Romania;

3. To identify the essential internal differences of the post-communist welfare state model.

The research uses methods of analysis of scientific literature, secondary statistical analysis, expert evaluation, descriptive analytical and comparative analysis.

\section{THE WELFARE STATE MODEL OF POST-COMMUNIST STATES AND ITS INTERNAL DIFFERENCES}

The scientific literature reveals dialogue and some contradictions between scientists and researchers - some authors are convinced that post-communist states are developing on the path of G. Esping-Andersen's welfare regimes, but most authors (Sengoku, Horibayashi, Pop-Radu, Aidukaite, etc.) are of the opinion that post-communist states' social policies are not of the welfare state type, and post-communist states are characterized by a unique and mixed system in which the features of the different Esping-Andersen models intertwine. This is what allows post-communist states to be identified, assessed and analysed as a separate welfare state model, that has no analogues (Kääriäinen, Lehtonen 2006). 
However, demonstrating the integrity of the post-communist model and assigning all post-communist states to one model is quite difficult and probably even impossible because post-communist countries differ from one another. For example, the Czech Republic and Slovenia are much closer to a social democratic model of social policy, while Estonia, Latvia and Lithuania are moving towards a more liberal welfare state model (Žalimienè et al. 2011).

Here, in examining welfare regimes in post-communist states, H. J. M. Fenger emphasizes that the countries of Central and Eastern Europe are very different from the traditional typology of European welfare regimes formulated by Esping-Andersen (Fenger 2007). According to Fenger, the development and institutional framework of some countries are strongly affected by their choice to join the European Union, others, such as Moldova and Ukraine, are heavily influenced by Russia and Belarus cannot be considered in the general context, as it is a 'military state'. It would therefore be wrong to classify all post-communist states as one type.

I. Tache and C. Neesham agree that the countries of Central and Eastern Europe have mixed features, and therefore propose that the countries in the region should be divided into two subgroups: the self-reliance (the Baltic States, Slovakia, Bulgaria and Romania) and the welfare states (the Czech Republic, Hungary, Poland and Slovenia) (Tache, Neesham 2011). The first group has the characteristics of a neoliberal regime, the second group has more similarities with the continental (corporate-conservative) model of Western Europe. The authors note that all these states also have such features in common as social inequality and the polarization of societies.

In his research, M. Sengoku showed that post-communist states differed not only from other parts of the world, but also among themselves, for example, the Czech Republic had a more universal system, Poland tended toward a liberal system and Hungary was an intermediate between the two systems. According to the author, it would be expedient to base the interpretation of differences between post-communist states on national policy, and more precisely on the state party system and its strategic configuration (Sengoku 2006). Some authors seek to exclude the Baltic States from the group of post-communist states (Draxler et al. 2010), because in these states there are exceptionally coexisting and overlapping types of liberal and conservative-corporate welfare regimes, which are also influenced by the communist experience.

Thus, although the welfare regimes of post-communist countries do not fit into the traditional typology of welfare regimes, they are unique and have no analogues in the rest of the world, but fundamental differences also exist between the post-communist states themselves. This is what gives the analysis of the welfare regimes of post-communist states uniqueness, relevance and interest.

\section{COMPARATIVE ANALYSIS OF THE CZECH REPUBLIC, LITHUANIA AND ROMANIA}

The majority of Central and Eastern European post-communist countries can be divided into three groups: Central European countries (the Czech Republic, Poland, Slovakia and Hungary), the Baltic countries (Lithuania, Latvia and Estonia) and South-Eastern European countries (Bulgaria and Romania). In order to make a comparison of the countries in the post-communist welfare states model, the authors selected three countries, each of which corresponds to a different group of post-communist states: the Czech Republic, Lithuania, and Romania.

The states that liberated themselves from the Soviet Union and abandoned the Soviet social model faced a clear challenge - how to successfully and effectively carry out transformation, make fundamental economic and social transformations, democratizing the political 
system and rebuilding the institutional apparatus itself. In the first years of transformation, the priorities of post-communist states were focused on political and economic aspects, while social policy and the social security system were completely abandoned (Sengoku 2006). In short - after the end of communist rule, a phase of transformation began. According to political scientist L. Gudžinskas, such a transformation should be considered as a multifaceted process, during which not only democratic and market economy institutions were established, but also all governance structures in general were reorganized (Gudžinskas 2014) and the process of transformation has created opportunities to reform welfare policies as well. However, the question remains open: how did states manage to seize these opportunities?

It is accession to the European Union that marks the end of this transformation. This can be argued by the fact that membership of the European Union, in particular, creates opportunities for structural reforms of the welfare state and allows for the exchange of 'good practices'. Accession to the European Union is understood as a kind of turning point, a border, which means setting new priorities and solving entrenched problems. For example, basic social rights are enshrined in the Charter of Fundamental Rights of the European Union (for example, the right to social assistance), which is binding on all member states of the European Union. Finally, the poorer members of the European Union receive huge amounts of structural support, which they can direct to the necessary reforms, in order to create prosperity for their citizens. In this regard, the article analyses states in the context of the European Union, that is, since the accession to the European Union. The Czech Republic and Lithuania became members of the European Union already in the middle of 2004, so they will be evaluated from 2005, while Romania joined the European Union on 1 January 2007, so the analysis will be conducted from this date.

\section{TRANSFORMATION OF THE CZECH REPUBLIC}

After the collapse of the communist regimes, the Czech Republic saw a combination of partly spontaneous, partly controlled rapid processes of political, economic and social change. Three phases of the development and expansion of Czech social policy can be identified (Potuček et al. 2004):

The first phase can be described as the creation of new institutions, which lasted from about 1989 to 1992. Given that the Czech Republic became an independent state in 1993, social policy was developed at two levels: federal (Czechoslovak Ministry of Labor and Social Affairs) and national (Ministry of Labor and Social Affairs of the Czech Republic). Cooperation between the two ministries was not always ideal, and approaches were often inconsistent. However, through their activities, both ministries sought to create more elastic and decentralized mechanisms, and to develop and establish a universal and unified social welfare system. Such a system was to provide compulsory health and social insurance, as well as state social assistance in the event of exhaustion of all alternative assistance options or in the event of a citizen's inability to take care of himself. The second phase, which lasted from 1992 to 1998, would be best described as the savings phase (Potuček et al. 2004). As many political changes took place at the time and there was an increasing focus on economic reforms, spending on social protection was rather significantly limited. During the third phase, which began in 1998, social policy was returned to the main agenda. With the change of government, the ideology and practice of a socially oriented market economy prevailed. This meant that all citizens were given equal opportunities to education, work and so on. The third phase saw a stark contrast to the liquidating social policies pursued by the previous government. 


\section{TRANSFORMATION OF LITHUANIA}

After regaining its independence, the German corporate social security model was introduced in Lithuania in the 1990s, but later the search for a welfare model shifted towards a liberal model. However, as before, there is no clear direction or attitude of the makers of the social policy model in Lithuania. This was especially evident in the development of the Lithuanian Progress Strategy 2030, which formulated the aspiration for Lithuania to become similar to the Nordic welfare state, although the liberals established in power just sought to limit public services (Guogis 2014). In general, Lithuania does not have a methodologically based concept of the country's socio-economic long-term development as well as measures of its systematic implementation. Therefore, social policy in Lithuania was mainly focused on 'firefighting' rather than strategic, in-depth problem solving (Šileika, Paškevičiūtė 2013).

\section{TRANSFORMATION OF ROMANIA}

After years of social poverty and harsh economic conditions, Romania began to undertake structural and economic reforms and a historic transformation from a socialist system to a market economy in 1990. The need for such a transformation was prompted by the revolution that took place in the country in 1989 , after which social problems, especially rapidly rising unemployment, affected an increasing number of people. However, during the transformation, too little political attention was paid to social policy - it did not have clearly defined priorities and was implemented inconsistently. The country was plagued by poverty, the spread of social exclusion, low education, insufficient access to social services, and the formation of socially vulnerable groups - children, young people, the elderly, the homeless, the Roma and others. In addition, social policy has been characterized by path-dependency on communist heritage (Radutiu 2006). The political focus on social policy and social problems has increased only when Romania has been preparing for membership in the European Union. Substantial changes occurred in the creation of new institutions in the social field and the reorganization of existing ones. Thus, the formation of social policy was greatly influenced by the European Union, the requirements of which Romania, in order to meet, not only had to make various changes, but also had to formulate its social vision.

During the transformation, each of the three countries has inevitably faced various challenges and problems, some of which are so deeply rooted that even years later, and with many different economic, political and social reforms, they are still being felt. A separate analysis of each country makes it possible to paint a detailed picture of the country in detail, highlighting the strengths and weaknesses specific to a particular country. Together, this allows all three selected states to be brought together to assess the situation of each country in the context of other countries, and ultimately to show why it is still difficult to talk about a coherent welfare model of post-communist states.

It is noted that most authors suggest comparing and evaluating welfare states using fairly abstract criteria/indicators such as processes, influence, impact, etc. Such criteria can be interpreted broadly, and their assessment often depends on the author's subjective views or beliefs. In order to eliminate the element of subjectivity and possible interpretations, as well as to provide accuracy, certainty and easier systematization of data, for comparison it was chosen to analyze the criteria with numerical expression:

1. Financing welfare policies;

2. Purchasing power; 
3. Income inequality;

4. At-risk-of-poverty rate;

5. Happiness index;

6. Social justice index.

\section{FINANCING WELFARE POLICIES}

Every country faces the challenge of allocating resources fairly, guaranteeing their most efficient use and ensuring the well-being of its citizens. Therefore, the criterion for financing welfare policies includes the most important welfare policies for the state - social security policy, education policy and health care policy (Table 1). The criterion for financing welfare policies is understood as the government expenditure on each policy, calculated as a percentage of a country's GDP.

\section{Social Security}

During the period under review, the Czech Republic allocated the largest funds for social security - on the average $12.5 \%$. There is a sequence of increases in social security spending by each country since 2009, linked to the global banking and economic crisis of 2008 . Each of the analysed countries had different social security systems: in the Czech Republic, the social security system included pension, sickness and health insurance systems, a national employment policy system and a non-contributory social benefit system. In Lithuania, since

Table 1. Financing welfare policies

\begin{tabular}{c|c|c|c|c|c|c|c|c|c}
\hline \multirow{2}{*}{ Year } & \multicolumn{2}{|c|}{$\begin{array}{c}\text { Social security } \\
\text { (percentage of GDP) }\end{array}$} & \multicolumn{3}{c|}{$\begin{array}{c}\text { Education } \\
\text { (percentage of GDP) }\end{array}$} & \multicolumn{3}{c}{$\begin{array}{c}\text { Health care } \\
\text { (percentage of GDP) }\end{array}$} \\
\cline { 2 - 11 } & $\begin{array}{c}\text { Czech } \\
\text { Republic }\end{array}$ & $\begin{array}{c}\text { Lithu- } \\
\text { ania }\end{array}$ & $\begin{array}{c}\text { Roma- } \\
\text { nia }\end{array}$ & $\begin{array}{c}\text { Czech } \\
\text { Republic }\end{array}$ & $\begin{array}{c}\text { Lithu- } \\
\text { ania }\end{array}$ & $\begin{array}{c}\text { Roma- } \\
\text { nia }\end{array}$ & $\begin{array}{c}\text { Czech } \\
\text { Republic }\end{array}$ & $\begin{array}{c}\text { Lithu- } \\
\text { ania }\end{array}$ & $\begin{array}{c}\text { Roma- } \\
\text { nia }\end{array}$ \\
\hline 2005 & 11.7 & 9.8 & & 4.8 & 5.4 & & 6.9 & 4.9 & \\
\hline 2006 & 11.7 & 9.8 & & 4.9 & 5.4 & & 7.0 & 5.3 & \\
\hline 2007 & 11.9 & 10.7 & 10.0 & 4.7 & 5.3 & 3.9 & 6.8 & 5.2 & 3.6 \\
\hline 2008 & 11.9 & 12.1 & 11.0 & 4.7 & 6.1 & 4.3 & 6.9 & 5.6 & 3.6 \\
\hline 2009 & 13.1 & 16.4 & 13.1 & 5.1 & 7.2 & 3.8 & 7.8 & 6.7 & 4.0 \\
\hline 2010 & 13.2 & 14.1 & 13.9 & 5.1 & 5.9 & 3.3 & 7.8 & 7.0 & 4.2 \\
\hline 2011 & 13.2 & 12.4 & 13.0 & 5.1 & 5.6 & 4.1 & 7.7 & 6.7 & 4.2 \\
\hline 2012 & 13.3 & 12.0 & 12.4 & 5.0 & 5.4 & 3.0 & 7.7 & 5.9 & 3.8 \\
\hline 2013 & 13.5 & 11.4 & 11.5 & 5.1 & 5.2 & 2.8 & 7.6 & 5.6 & 4.0 \\
\hline 2014 & 13.1 & 11.4 & 11.4 & 5.1 & 5.0 & 3.0 & 7.6 & 5.5 & 4.0 \\
\hline 2015 & 12.5 & 11.1 & 11.4 & 4.9 & 5.1 & 3.1 & 7.6 & 5.8 & 4.2 \\
\hline 2016 & 12.3 & 11.2 & 11.5 & 4.5 & 4.8 & 3.3 & 7.4 & 5.8 & 4.0 \\
\hline 2017 & 12.0 & 11.2 & 11.7 & 4.1 & 4.5 & 2.8 & 7.5 & 5.6 & 4.3 \\
\hline 2018 & 12.0 & 12.1 & 11.6 & 4.6 & 4,6 & 3.2 & 7.6 & 5.9 & 4.7 \\
\hline Average & 12.5 & 11.8 & 11.9 & 4.8 & 5.1 & 3.4 & 6.9 & 5.8 & 4.1 \\
\hline
\end{tabular}

Source: Compiled by the authors on the basis of Eurostat data. 
the restoration of independence, the social security system has consisted of two parts - social insurance and social assistance. Social security programs were centralized, therefore the aim was to reduce the influence of the central government, transfer more social services to municipalities, increase the use of the non-state sector, and strengthen the capacity of the public administration. In Lithuania, a corporate-clientelistic type of social security was created, but even citizens of the country who did not participate in the labour market were entitled to benefits (Guogis 2002). Romania's social security policy has been relatively focused on Western welfare states, including freedom from employment, a minimum wage, holiday and unemployment benefits, as well as health care and pensions. The main target groups targeted by the social support system were families with insufficient income for minimum expenses, people with physical, sensory or mental disabilities, children with special needs, victims of domestic violence, the elderly, and the Roma population.

\section{Education}

In the period under review, the largest expenditures on education were allocated by Lithuania, on the average $5.1 \%$, and the lowest by Romania - only $3.4 \%$. Expenditure on education in Romania was the lowest during the whole period under review, in some years $(2013,2017)$ it did not even reach 3\%. In general, the education system in Romania has been inconsistent and volatile for a long time. Legislative provisions in the field of education have been constantly evolving since 1990. Each new Minister of Education had his own visions for reform, and as a result, constantly changed the provisions previously adopted. Curricula, study programs, even textbooks were changed, and the development of private higher education institutions was encouraged, thus increasing the number of students, etc. (Marin, Serban 2008). According to Eurostat, the share of persons aged 25-64 with the lowest secondary education in 2014 was as high as $27.2 \%$. There were also a large number of people in the country choosing to drop out of school. Higher education in the Czech Republic, meanwhile, enjoyed a high degree of academic freedom and a high level of autonomy. There were a large and growing number of private secondary and higher education institutions in the country. According to the Organization for Economic Co-operation and Development (OECD), as many as 92\% of people aged 25-64 had at least upper secondary education, well above the OECD average of $75 \%$. Finally, expenditure on education (as a percentage of GDP) was relatively high in Lithuania. According to the OECD, as many as $91 \%$ of people aged 25-64 in Lithuania had at least a secondary education. However, people with the teaching profession in Lithuania were among the most aging - almost half of the teachers were over 50 years old. Moreover, teachers earned much less than in other OECD countries, and their career prospects in terms of salary growth were extremely limited. Lithuania also faced the problem of 'brain drain' when professionals with higher education migrated to other countries - mainly due to low wages in the homeland. Currently, Lithuania is undergoing a major reorganization of higher education, when the number of universities in the country is being reduced by merging them and thus optimizing the existing programs.

\section{Health Care}

During the period under review, the highest spending on health care was in the Czech Republic, averaging 6.9\%, and the lowest in Romania, at $4.1 \%$. Health care in each of the countries analysed has undergone significant changes and significant reforms. In the case of the Czech 
Republic, health care has undergone many changes since the 1990s. In principle, a complete reconstruction of health care institutions was carried out when the health insurance system was established. At the same time, the privatization of almost all primary health care institutions, as well as the pharmaceutical industry, pharmacies, institutions providing spa services, etc., took place (Kinkorova, Topolčan 2012). Substantial changes in the health care system were made after 2005. The most important ones are the following: In 2005-2006, a new risk regulation scheme was implemented by redistributing social health insurance contributions between health insurance funds. In 2008, a fee for doctor visits, prescription drugs, hospital stays, etc. was introduced for persons using medical services (Kinkorova, Topolčan 2012). Various initiatives have also been taken to improve the quality of highly specialized healthcare. In the case of Lithuania, after the restoration of independence in 1991, only $7 \%$ of the population was satisfied with the quality of health care and as many as $80 \%$ were in favour of fundamental reforms in the field of health care (Gudžinskas 2012). The lack of quality health services, low salaries of doctors, lack of medicines, lack of private treatment practices and informal payments have necessitated changes in the health care sector. Although most of the reforms have been implemented inconsistently and late, however, there were implemented primary care reforms, compulsory health insurance reform, which means health care financing based on compulsory health insurance, control of most health care institutions has been transferred to municipalities, and hospitals have been restructured. In the case of Romania, it should be noted that significant reforms in the health system took place in 1999, with the entry into force of Law No. 145/1997 (Marin, Serban 2008). Health care funding has been modified, requirements for the provision of accreditation services have been granted, citizens have been given the freedom to choose doctors, new hospital wards have been set up, privatization of the distribution of pharmaceutical products has been completed, etc.. Overall, the health system in Romania has long been underfunded and damaged by mismanagement. Even now, the health system is highly centralized, many decisions are made only by the Minister of Health, resource allocation is carried out without clear criteria, and there are no clear guidelines for improving quality, patient safety and risk management (Suciu et al. 2012). These problems pose new problems. For example, low funding leads to the migration of medical staff in search of better working conditions, higher salaries. The problems of mismanagement are leading to high levels of medical negligence, leading to more and more cases in the courts.

\section{PURCHASING POWER}

The standard of purchasing power and the standard of living can be compared on the basis of the prices of various goods and services in each country in terms of income, expressed as a common contractual indicator. The Purchasing Power Standard (PPS) is an artificial currency unit used in the European Union to express the volume of economic indicators and to make comparisons in space. One purchasing power standard corresponds to the same set of goods and services in all countries, but in each country, depending on the price level, a different amount of national currency is needed to buy this set of goods and services. Comparing GDP per capita in purchasing power standard units shows the standard of living in various countries of the European Union. In other words, the purchasing power standard eliminates differences in price levels between countries. Thus, this indicator is expressed as GDP per capita in purchasing power standard units (Table 2).

The highest purchasing power in terms of GDP per capita in purchasing power parity was in the Czech Republic over the period under review, averaging almost $85 \%$, and the lowest in 
Table 2. Purchasing power

\begin{tabular}{c|c|c|c}
\hline \multirow{2}{*}{ Year } & \multicolumn{3}{|c}{ Purchasing power (percent) } \\
\cline { 2 - 4 } & Czech Republic & Lithuania & Romania \\
\hline 2005 & 81 & 53 & \\
\hline 2006 & 84 & 56 & 42 \\
\hline 2007 & 84 & 61 & 48 \\
\hline 2008 & 82 & 63 & 49 \\
\hline 2009 & 83 & 57 & 50 \\
\hline 2010 & 81 & 60 & 51 \\
\hline 2011 & 83 & 65 & 54 \\
\hline 2012 & 82 & 70 & 54 \\
\hline 2013 & 84 & 73 & 55 \\
\hline 2014 & 86 & 75 & 56 \\
\hline 2015 & 87 & 75 & 59 \\
\hline 2016 & 88 & 75 & 63 \\
\hline 2017 & 89 & 78 & 64 \\
\hline 2018 & 90 & 81 & 53.8 \\
\hline Average & 84.6 & 67.3 & \\
\hline
\end{tabular}

Source: Compiled by the authors on the basis of Eurostat, World Bank Data, SGI-network data.

Romania averaging around 54\%. The difference between the Czech Republic and Romania is on the average more than $30 \%$. In all countries, there has been an increase in purchasing power in recent years. It is noted that the biggest change is observed in Lithuania, where purchasing power increased by as much as $28 \%$ during the period under review (from $53 \%$ in 2005 to $81 \%$ in 2018).

\section{INCOME INEQUALITY}

The Gini Coefficient can be used to estimate income inequality (Table 3). The Gini Coefficient can be termed as a measure of income inequality. The Gini Coefficient is used to determine the ratio between the cumulative share of the population broken down by size of income and the cumulative total they receive. If each person received the same income, this ratio would be equal to 0 percent. If all national income were in the hands of just one person, then the coefficient would be 100 percent (Lisauskienè 2010). Thus, the higher the ratio, the greater the inequality of income distribution in the country.

The largest income inequality is observed in Lithuania, on the average 35.5 percent. Lithuania has one of the largest income inequalities in the entire European Union. Income inequality in Lithuania was formed immediately after the restoration of independence. This was due to rising unemployment, land reforms and privatization, which were detrimental to the majority of the population (Masso et al. 2012). A. Lazutka identifies the reason of high income inequality as the focus only on GDP growth, but not on its distribution (Lazutka 2003). According to the author, Lithuania is characterized by high income inequality and low social security expenditures, while in countries with the highest social security expenditures, income inequality is significantly lower. There is also a significant 
Table 3. Income inequality

\begin{tabular}{c|c|c|c}
\hline \multirow{2}{*}{ Year } & \multicolumn{3}{|c}{ Income inequality (Gini Coefficient, \%) } \\
\cline { 2 - 4 } & Czech Republic & Lithuania & Romania \\
\hline 2005 & 27.0 & 35.3 & \\
\hline 2006 & 26.7 & 34.4 & 37.6 \\
\hline 2007 & 26.0 & 34.6 & 29.4 \\
\hline 2008 & 26.3 & 37.1 & 34.5 \\
\hline 2009 & 25.1 & 35.9 & 33.5 \\
\hline 2010 & 24.9 & 37.0 & 33.5 \\
\hline 2011 & 25.2 & 33.0 & 34.0 \\
\hline 2012 & 24.9 & 32.0 & 34.6 \\
\hline 2013 & 24.6 & 34.6 & 35.0 \\
\hline 2014 & 25.1 & 35.0 & 37.4 \\
\hline 2015 & 25.0 & 37.9 & 34.7 \\
\hline 2016 & 25.1 & 37.0 & 33.1 \\
\hline 2017 & 24.5 & 37.6 & 35.1 \\
\hline 2018 & 24.0 & 35.6 & 34.4 \\
\hline Average & 25.3 & 35.5 & \\
\hline
\end{tabular}

Source: Compiled by the authors on the basis of Eurostat, World Bank Data, SGI-network data.

income inequality in Romania. Although, according to the data presented in the table, income inequality has been consistently reduced over the period under review, the indicators remain high. The largest income inequality gap in Romania is between wage earners and the self-employed (Domnisoru 2014). Another argument for a high income inequality is linked to the high levels of corruption that have prevailed in the country. Corruption covered most public sectors. It is corruption that has led to a disproportionate distribution of resources, with most of them concentrated in the hands of the upper class (Leeson, Linderfelser 2013). Meanwhile, a weak, often corrupt judicial system does not provide citizens with access to justice. Finally, the Czech Republic has the lowest income inequality, averaging 25.3\%. In the Czech Republic, middle-income earners are the main victims of income inequality. Interestingly, Prague is the only region in the whole country where incomes are higher than the national average and that the gap that increases income inequality is only widening (Kahanec et al. 2012). According to the Gini Coefficient, income inequality in the country is relatively low.

\section{AT-RISK-OF-POVERTY RATE}

Behind the At-risk-of-poverty Rate Indicator is the country's prerogative to protect or alleviate the situation of the population at social risk (Table 4). The means and methods of combating poverty vary from country to country, and the results of this fight vary as well. It is possible to rely on the European Union poverty measurement methodology, according to which the relative poverty line is used to calculate the At-risk-of-poverty Rate, which is equal to $60 \%$ of the median equivalent monetary disposable income (Šileika, Zabarauskaitè 2009). 
Table 4. At-risk-of-poverty Rate

\begin{tabular}{cccc}
\hline \multirow{2}{*}{ Year } & \multicolumn{3}{|c}{ At-risk-of-poverty Rate (percent) } \\
\cline { 2 - 4 } & Czech Republic & Lithuania & Romania \\
\hline 2005 & 19.6 & 41.0 & \\
\hline 2006 & 18.0 & 35.9 & 45.9 \\
\hline 2007 & 15.8 & 28.7 & 44.2 \\
\hline 2008 & 15.3 & 28.3 & 43.1 \\
\hline 2009 & 14.0 & 29.6 & 41.4 \\
\hline 2010 & 14.4 & 34.0 & 40.3 \\
\hline 2011 & 15.3 & 33.4 & 41.7 \\
\hline 2012 & 15.4 & 32.5 & 41.9 \\
\hline 2013 & 14.6 & 30.8 & 40.3 \\
\hline 2014 & 14.8 & 27.3 & 37.4 \\
\hline 2015 & 14.0 & 29.3 & 38.8 \\
\hline 2016 & 13.3 & 30.1 & 35.7 \\
\hline 2017 & 12.2 & 29.6 & 32.5 \\
\hline 2018 & 12.2 & 28.3 & 40.3 \\
\hline Average & 14.9 & 31.3 & \\
\hline
\end{tabular}

Source: Compiled by the authors on the basis of Eurostat, World Bank Data, SGI-network data.

Assessing the At-risk-of-poverty Rate shows a very large gap between the countries in question. In the Czech Republic, the At-risk-of-poverty Rate averages just $14.9 \%$ and has never exceeded 20\% during the period under review. Overall, the Czech Republic has one of the lowest at-risk-of-poverty rates in the European Union. The groups most at risk of poverty are single parents, pensioners and Roma people (Svihlikova 2015). It is single parents, especially women, who are the highest group at risk of poverty (as much as 35\%). The significant problem of evasion of maintenance in the Czech Republic also contributes to this significant number. Despite the low risk of poverty, the country still has various programs and initiatives to help the poor. For example, non-governmental organizations and the Church are actively involved in food distribution programs, winter aid programs where people are given winter clothes, food and a place to live (Lazarová 2013). In Romania, meanwhile, the Atrisk-of-poverty Rate averages over $40 \%$ over the period under review. During the period under review, the lowest rates in Romania were recorded in 2018, when the At-risk-of-poverty Rate was $32.5 \%$. The poverty rate in Romania is extremely high. In Romania, there is a huge rural-urban divide, which means that the majority of people experiencing poverty are rural (Precupetu et al. 2015). Large families, people under the age of 18 and the Roma minority are also at risk of poverty. In Lithuania, which can be placed in the middle of the period under review, the At-risk-of-poverty Rate is quite high, although since 2016 there has been a declining trend in the level of poverty. Three groups of the population that are most at risk of poverty in Lithuania can be distinguished: rural residents, pensioners and single parents. Self-employed, employers and couples without children face the lowest risk of poverty (Šileika, Zabarauskaitè 2009). 
The Happiness Index is calculated taking into account life expectancy, freedom, level of corruption, social support, etc. This index is made up and calculated by the Sustainable Development Solutions Network. The Happiness Index report was first published in 2012, when data for 2005-2007 were evaluated. From 2018, the Happiness Index reports are published annually, including the results of the previous year. The index is calculated using data from surveys (respondents' own life assessments), combined with assessments by economic and psychological experts and national statistics. The Happiness Index is calculated based on indicators such as GDP, social support, access to medicine, personal boats, prevalence of corruption, and more. Assessing the indicators of the Happiness Index, it is noticeable that the Czech Republic maintains the best positions, which, moreover, managed to rise to the 19th place in the list (out of 156 possible). Lithuania and Romania also rank quite high on the list, with Romania's jump from 90th place in the first ratings (2005-2007) to 47th place in the last 2017-2019 ratings and Lithuania's jump from 71st place in the first ratings to 41st place in the last ratings being particularly noticeable.

The Social Justice Index is based on quantitative and qualitative data collected by the Bertelsmann Foundation in Germany. This index is calculated taking into account poverty prevention, education, access to the labour market, social cohesion, health, intergenerational relations, etc. The study calculated and compared the indicators of the European Union countries with expansion to OECD countries in the last year. Assessing the results obtained, the best achievements in the context of social justice are observed in the Czech Republic, rose from 6th place in 2008 to 4th place in 2017 (out of 28 possible) and 8th place in 2019. The Social Justice Index report highlights the commendable achievements of the Czech government in preventing poverty, as well as the favourable opportunities for access to the labour market. On the other hand, despite the truly excellent results in the Czech Republic, the social exclusion of specific groups, especially the Roma, remains a serious problem. The worst results are observed in Romania, which took only 27 th place (out of 28 possible) or 39 th (out of 41 possible). In terms of EU countries, worse results than in Romania were recorded Only in Greece (2014-2017), while in 2019, Romania was rated the worst of all EU countries (39th place). The Social Justice Index report emphasizes that Romania's extremely poor performance compared to other European Union countries demonstrates the need to implement the necessary political reforms in the country as soon as possible. The report states, among other things, that Romania is unable to provide its citizens with access to quality health care, and that poverty prevention remains one of the key policy challenges facing the Romanian government on a regular basis. Finally, the Roma are repeatedly mentioned as being particularly vulnerable to poverty and exclusion, who are constantly faced with various forms of discrimination, and the report also identifies them as a particularly serious problem and challenge for Romania as a whole. Meanwhile, Lithuania remains in the middle, but only Lithuania's results in 2015 allowed it to be above the EU average (14th place), in all other cases, Lithuania lagged behind the EU average by one or two positions, and in 2019, Lithuania lags behind the EU and OECD average by ten positions (31st place). The Social Justice Index report mentions the education system as the strongest place in Lithuania, which ensures equal educational opportunities and is distributed fairly. However, the report highlights the weaknesses of Lithuania far more than the strengths, such as poverty, social exclusion, high

It should be noted that in 2008-2017 only the indicators of the EU (28) countries were calculated, and in 2019 the list of the countries of the International Organization for Economic Co-operation and Development (OECD) was included in the report, thus the list of analysed countries expanding to 41 states. 
unemployment, especially among young people and the low-skilled, and long-term unemployment. Finally, the study identified the provision of health care services as one of the weakest points in Lithuania, especially due to the extremely frequent out-of-pocket payments. According to experts, this is the most sensitive area where gradual policy reforms are most needed.

Thus, although post-communist states can be combined into one whole, the analysis draws clear boundaries between the selected states and shows that these states have significant differences among themselves. On the basis of the data provided, it can be stated that, compared to the other analysed countries, the Czech Republic has the most generous funding of welfare policies, the best estimate of living standards and the most favourable economic environment. The Czech Republic is a strong welfare state, creating a decent economic environment for its citizens, adequately funding welfare policies and ensuring a good standard of living. Meanwhile, of the analysed countries, Romania is not only in the worst position, but often the gap with the rest is particularly pronounced. Romania's worst performance, and its excessive gap with the Czech Republic, not only makes it possible to unite the two countries into one whole, but also to treat them as equal countries. It also proves that it is wrong to consider Romania as an established welfare state. Finally, in terms of the indicators obtained, Lithuania, which often finds itself in the middle between the Czech Republic and Romania, remains in a unique position. Lithuania in the context of the welfare state can be assessed in two ways. On the one hand, Lithuania does not have high welfare-specific indicators, for example, due to a very high risk of poverty. In addition, a country suffers from unemployment problems, and happiness or social justice indices indicate a country as only average. On the other hand, when evaluating Lithuania, its potential is revealed, therefore it should be considered as a progressive and potential country in the context of the welfare state.

\section{CONCLUSIONS}

1. The study of welfare states, after the substantiation of the classical typologies of R. Titmuss and G. Esping-Andersen, is being developed by other authors, one of the original works of which is the modelling of post-communist Central and Eastern European states.

2. Despite some similarities in the Central and Eastern European countries, they show significant differences in the field of welfare provision, as evidenced by the statistical and comparative analysis of the Czech Republic, Lithuania and Romania.

3. Differences between these countries are evidenced by comparable criteria for financing welfare policies in social security, education and health, as well as in purchasing power, income inequality, at-risk-of-poverty rates, happiness and social justice indices.

4. It can be argued that it is scientifically difficult to speak of a coherent post-communist welfare state model.

5. Several models of welfare states should be defined in Central and Eastern Europe, and the Czech Republic, Lithuania and Romania could represent them in three different groups of CEE states. The Czech Republic would represent the group of the most developed CEE countries, Romania the group of the least developed countries, and Lithuania, as the representative of the Baltic States, would occupy an intermediate position among these countries.

6. As a result of the 2020 COVID-19 health, administration and economic crisis, it can be predicted that the challenges of building welfare states will change both globally and in Central and Eastern Europe, which may also affect welfare state modelling questions and answers. 


\section{References}

1. Domnisoru, C. 2014. 'The Largest Drop in Income Inequality in the European Union during the Great Recession: Romania's Puzzling Case', Conditions of Work and Employment Series 51.

2. Esping-Andersen, G. 1990. The Three Worlds of Welfare Capitalism. Princeton: Princeton University Press.

3. Fenger, H. J. M. 2007. 'Welfare Regimes in Central and Eastern Europe: Incorporating Post-communist Countries in a Welfare Regime Typology', Contemporary Issues and Ideas in Social Sciences 3: 1.

4. Gudžinskas, L. 2014. „Europeizacija ir gerovès valstybė Lietuvoje: institucinès sankirtos“, Politologija 76(4): 124-155.

5. Gudžinskas, L. 2012. „Lietuvos ir Estijos sveikatos apsaugos raida: panašios sąlygos skirtingi rezultatai“, Politologija 67(3): 61-94.

6. Guogis, A. 2002. „Dèl Lietuvos socialinès politikos modelio“, Politologija 28(4): 76-95.

7. Guogis, A. 2014. „Kai kurie socialiniai-politiniai gerovès valstybių kūrimo Europoje ir Lietuvoje aspektai", Filosofija. Sociologija 25(2): 71-79.

8. Kääriäinen, J.; Lehtonen, H. 2006. 'The Variety of Social Capital in Welfare State Regimes - a Comparative Study of 21 Countries', European Societies 8: 1.

9. Kahanec, M.; Guzi, M.; Martišková, M.; Paleník, M.; Pertold, F.; Siebertová, Z. 2012. GINI Country Report: Growing Inequalities and Their Impacts in the Czech Republic and Slovakia. Country Report for the Czech Republic and Slovakia. Available at: https://gini-research.org/system/uploads/511/original/Czech_Slovak. pdf?1377869960 (accessed 26.05.2020).

10. Kinkorova, J.; Topolčan, O. 2012. 'Overview of Healthcare System in the Czech Republic', EPMA Journal 3: 1.

11. Lazarová, D. 2013. 'Close to a Million Czechs Threatened by Poverty', Český Rozhlas, October 2013. Available at: https://www.radio.cz/en/section/curraffrs/close-to-a-million-czechs-threatened-by-poverty (accessed 26.05.2020).

12. Lazutka, R. 2003. „Gyventojų pajamų nelygybë“, Filosofija. Sociologija 15(2).

13. Leeson III, J.; Linderfelser, M. 2013. 'Income Inequality: United States vs. Romania', Undergraduate Journal of Global Citizenship 1: 3.

14. Lisauskienè, V. 2010, „Lietuvos gyventojų pajamų ir vartojimo diferenciacija“, Verslas: teorija ir praktika 11(3): 266-278.

15. Marin, M.; Serban, M. 2008. Trends in the Field of Social Policies and Welfare Reforms in Romania. Available at: https://www.cespi.it/sites/default/files/documenti/breport_romania.pdf (accessed 26.05.2020).

16. Masso, J.; Espenberg, K.; Masso, A.; Mierina, I.; Philips, K. 2012. GINI Country Report: Growing Inequalities and Its Impacts in the Baltics. Country Report for The Baltic States Estonia, Latvia, Lithuania. Available at: https://gini-research.org/system/uploads/437/original/Baltics.pdf?1370077200 (accessed 26.05.2020).

17. Moreno, L. 2016. Post-Crisis and the Bronze Age of Welfare in Europe. Working Paper 1. Instituto De Politicas Y Bienes Publicos (IPP).

18. Potuček, M.; Mašková, M.; Ochrana, F.; Kuchař, P. 2004. Czech Welfare State: Changing Environment, Changing Institutions. Available at: https://www.ceses.cuni.cz/CESES-20-version1-sesit04_07_potucek. pdf (accessed 26.05.2020).

19. Precupetu, I.; Preoteasa, A. M.; Vlase, I. 2015. 'Beyond Poverty in Romania: An Analysis of HouseholdLevel Factors of Poverty and Precarious Porsperity', Sociológia 47: 3.

20. Radutiu, S. V. 2006. 'Social Policy Reform in Post-communist Romania: Facing the EU Changes', CEU Political Science Journal 1: 4.

21. Sengoku, M. 2006. Emerging Eastern European Welfare States: A Variant of the 'European'Welfare Model? Available at: https://src-h.slav.hokudai.ac.jp/coe21/publish/no2_ses/3-2_Sengoku.pdf (accessed 26.05.2020).

22. Šileika, A.; Paškevičiūtè, J. 2013. „Lietuvos tapsmo gerovès valstybe prieštaros“, Ekonomika ir vadyba: aktualijos ir perspektyvos 1(29): 8-19.

23. Šileika, A.; Zabarauskaitè, R. 2009 „Skurdas: Metodologijos klausimai ir lygis Lietuvoje“, Socialinis darbas 8(1): 17-27.

24. Suciu, M. C.; Stan, C. A.; Piciroş, L.; Imbrişcă, C. I. 2012. 'The Post-Crisis Healthcare System: Effects of the Economic Crisis in Romania, Theoretical and Applied Economics 19: 5.

25. Svihlikova, I. 2015. 'Poverty and Inequality in the Czech Republic', Transform Network, 10 October. Available at: https://www.transform-network.net/blog/blog-2015/news/detail/Blog/poverty-and-inequality-in-the-czech-republic.html (accessed 26.05.2020). 
26. Tache, I.; Neesham, C. 2011. 'The Performance of Welfare Systems in Post-Communist Europe: The Cases of Romania and Bulgaria', International Journal of Economics and Research 2: 5.

27. Titmuss, R. M. 1974. 'What is Social Policy?' in Welfare States: Construction, Deconstruction, Reconstruction, eds. S. Leibfried and S. Mau. Cheltenham, Northampton: Edward Elgar Publishing.

28. Žalimienė, L.; Lazutka, R.; Skučienė, D.; Aidukaitė, J.; Kazakevičiūtė, J.; Navickė, J.; Ivaškaitė-Tamošiūnè, V. 2011. Socialinis teisingumas švietime: teorine samprata ir praktinis vertinimas. Prieiga per internetą: https:// www.smm.lt/uploads/lawacts/docs/693_f31fc7ad3da4f678e4cb208806e76b91.pdf (žiūrèta 2020-05-26).

29. Bertelsmann Stiftung. Social Justice Index. Available at: https://www.social-inclusion-monitor.eu/social-justice-index/

30. Eurostat. Available at: https://ec.europa.eu/eurostat

31. Nuffic. Education Systems Worldwide. Available at: https://www.nuffic.nl/en/

32. OECD. Available at: www.oecd.org/

33. SGI Network. Available at: https://www.sgi-network.org/

34. World Bank Data. Available at: https://data.worldbank.org/

35. World Happiness Report. Available at: https://worldhappiness.report/

GIEDRĖ SVIRBUTAITĖ-KRUTKIENĖ, ARVYDAS GUOGIS

\title{
Kodèl sudẻtinga kalbẻti apie (vientisą) pokomunistinị gerovès valstybès modelį? Čekijos, Lietuvos ir Rumunijos lyginamoji analizè
}

\begin{abstract}
Santrauka
Gerovès valstybių tyrimas, po klasikinių R. Titmusso ir G. Esping-Anderseno tipologiju pagrindimo praejjusio amžiaus pabaigoje, yra plètojamas kitų autorių, kurių vienu iš originalių darbų objektų yra tapęs pokomunistinių Centrinès ir Rytų Europos (CRE) valstybių modeliavimas. Nepaisant tam tikrų panašumų CRE šalyse, jos pasižymi ir ryškiais skirtumais gerovès aprūpinimo srityje - tai patvirtina Čekijos, Lietuvos ir Rumunijos statistinè bei lyginamoji analizè. Skirtumus tarp šių šalių ịrodo palyginamieji gerovès politikų socialinès apsaugos, švietimo ir sveikatos apsaugos finansavimo kriterijai, taip pat perkamosios galios, pajamų nelygybès, skurdo rizikos lygio rodikliai, laimès ir socialinio teisingumo indeksai. Straipsnio autoriai teigia, kad moksliniu požiūriu yra sudètinga kalbėti apie vientisą pokomunistinį gerovès valstybės modelį. Reikètų apibrèžti kelis gerovès valstybių modelius CRE, o Čekija, Lietuva ir Rumunija galètų juos reprezentuoti trijose skirtingose CRE valstybių grupèse. Čekija atstovautų labiausiai išsivysčiusiai CRE šalių grupei, Rumunija - mažiausiai išsivysčiusiai, o Lietuva, kaip Baltijos šalių atstové, užimtų tarpinę padètị tarp šių šalių.
\end{abstract}

Raktažodžiai: gerovès valstybès modelis, socialinis modelis, pokomunistinès valstybès 